\title{
Comparison of Anesthesia Quality for Arthroscopic Knee Surgery: Combined Sciatic Femoral Block and Unilateral Spinal Anesthesia
}

\section{Artroskopik Diz Cerrahisi için Anestezi Kalitesinin Karşılaştırılması: Kombine Siyatik Femoral Blok ve Tek Taraflı Spinal Anestezi}

\author{
Sinem Sarı ${ }^{1}$, Füsun Eroğlư ${ }^{2}$, Pierfrancesco Fusco ${ }^{3}$, Tolga Atay ${ }^{4}$, Berit Gökçe Ceylan ${ }^{2}$ \\ ${ }^{1}$ Adnan Menderes University Faculty of Medicine, Department of Anesthesiology, Aydın, Turkey \\ ${ }^{2}$ Süleyman Demirel University Faculty of Medicine, Department of Anesthesiology, Isparta, Turkey \\ ${ }^{3}$ Laquila University San Salvatore Hospital, Department of Anesthesiology, Laquila, Italy \\ ${ }^{4}$ Süleyman Demirel University Faculty of Medicine, Department of Orthopedics and Traumatology, Isparta, Turkey
}

Key words

Sciatic and femoral nerve block, unilateral spinal anesthesia, levobupivacaine

Anahtar kelimeler

Siyatik femoral blok, tek taraflı spinal anestezi, levobupivakain

Received/Geliş Tarihi : 23.07 .2015

Accepted/Kabul Tarihi : 23.08.2015

doi:10.4274/meandros.2389

Address for Correspondence/Yazışma Adresi: Sinem Sarı MD,

Adnan Menderes University Faculty of Medicine, Department of Anesthesiology, Aydın, Turkey

Phone : +90 2562120146

E-mail : sarisinem@yahoo.com

(C) Meandros Medical and Dental Journal, published by Galenos Publishing.

(c) Meandros Medical and Dental Journal, Galenos Yayınevi tarafından basılmıştır.

\begin{abstract}
Objective: We aimed to evaluate the quality of anesthesia of combined sciatic and femoral 3-in-1 nerve blocks (CSFB) and unilateral spinal anesthesia technique with low-dose levobupivacaine in outpatients undergoing knee arthroscopy surgery.

Materials and Methods: Forty American Society of Anesthesiologists (ASA) physical status I-II patients were randomly allocated into two groups and unilateral spinal anesthesia with low-dose levobupivacaine (group $S, n=20$ ) or CSFB (group $B$, $n=20$ ) was performed. Besides the quality of anesthesia, anesthetic effectiveness, hemodynamic values, duration of the technique application, maximum motor and sensorial block levels and durations, the first analgesics need, and total analgesic consumptions during postoperative 24 hours and determined complications were compared between the two groups.

Results: The quality of anesthesia was better in group $\mathrm{S}$, no patient received either sedation or analgesic intraoperatively while first analgesic need and number of patient was higher $(p=0.014, p<0.001, p=0.032$ respectively). The duration of technical application was shorter while maximum motor and sensorial block levels were higher in group $S(p<0.0001, p=0.008, p<0.001$ respectively). Motor block duration was significantly longer in group $B(p<0.0001)$.

Conclusion: We concluded that CSFB practice is an effective anesthetic alternative for unilateral spinal anesthesia.
\end{abstract}

\section{Özet}

Amaç: Günübirlik diz artroskopisi cerrahisinde kombine siyatik ve femoral üçü bir arada blok ile düşük doz levobupivakain ile yapılan tek taraflı spinal anestezi tekniklerinin anestezi kalitesini değerlendirmeyi amaçladık.

Gereç ve Yöntemler: American Society of Anesthesiologists (ASA) I-II 40 hasta rastgele iki gruba ayrıldı ve tek taraflı spinal anestezi (grup $S, n=20$ ) veya kombine siyatik ve femoral üçü bir arada blok (grup $B, n=20$ ) uygulandı. Anestezi kalitesinin yanı sıra, hemodinamik değerler, teknik uygulama süresi, maksimum motor ve duyusal blok düzey ve süreleri, ilk analjezik gereksinimi ve postoperatif 24 saat süresince toplam analjezik tüketimi, saptanan komplikasyonlar iki grup arasında karşılaşııııldı. 
Bulgular: Grup S'de operasyon sonrası ilk analjezik ihtiyacı ve analjezik uygulanan hasta sayısı daha yüksek iken anestezi kalitesi daha iyiydi ( $p<0,0001, p=0,032, p=0,014$ sırasıyla). Maksimum motor ve duyusal blok düzeyleri grup S'de daha yüksek iken teknik uygulama süresi daha kısaydı ( $p<0,001, p=0,008, p<0,0001$ sırasıyla). Motor blok süresi grup B'de anlamlı olarak uzundu $(p<0,0001)$.

Sonuç: Kombine siyatik ve femoral üçü bir arada blok uygulamasının, tek taraflı spinal anesteziye etkin ve alternatif bir yöntem olduğu sonucuna vardık.

\section{Introduction}

Arthroscopic knee surgery is a common outpatient surgical procedure (1). Regional anesthesia is an alternative method to general anesthesia. It has been demonstrated that regional anesthesia significantly reduces the morbidity by decreasing the occurrence of deep vein thrombosis, pulmonary embolism, transfusion requirement, pneumonia, depression of respiration, myocardial infarction, and renal failure $(2,3)$. Bradycardia, which occurres below the block level in the regional anesthesia, and develop by the vasodilatation-inducedhypotension, and sympathetic denervation, can increase the severity of the condition of patients especially with cardiac problems or elderly people (4). Therefore, peripheral nerve blocks have becomepopularin theoutpatient surgery for providing stable hemodynamic parameters, lower frequency of vomiting and quick recovery (5).

Even though,thepopularity of the use of peripheral nerve blocks is increasing in recent years, it has not become as common as spinal anesthesia due to lack of peripheral nerve block specialists and longer procedure duration. The advantages of unilateral spinal anesthesia over bilateral spinal anesthesia are low cardiovascular side effects, strong blockade during surgery using low doses, fewer hospitalization; and the disadvantage is that it requires protecting the lateral position for a while (6-8). When the side effects of peripheral block applications, such as pain in the application area and the side effects of spinal anesthesia, such as headache, urinary retention, and spinal hematoma are compared, peripheral block is a good alternative to spinal anesthesia. In addition, the hospitalization is further shortened (8).

In this present study, it was aimed to compare to the quality of anesthesia between, CSFB and unilateral spinal anesthesia with low doses of levobupivacaine in patients who undergo arthroscopic knee surgery.

\section{Materials and Methods}

Atotalof40 patients, whowereplanningtoundergo arthroscopic surgery under regional anesthesia in the orthopedics and traumatology clinics at Suleyman Demirel University, were included in the study. After the approval of the Hospital Ethical Committee, the consents of the participants were obtained. The patientshadan American Society of Anesthesiologists (ASA) physical status of I or II, and their age ranged from 18 to 70 years. Patients receiving chronic analgesics treatment as well as those with diabetes or peripheral neuropathies, allergy or hypersensitivity to local anesthetics, infection or hematoma at the puncture site and coagulation disorders were excluded from the study.

The patients were randomized into two study groups by closed envelope method, each with 20 patients: spinal anesthesia (group $S$ ) and femoral 3-in-1 nerve blocks (CSFB) (group B). The age, gender, weight, height, ASA scores of the participants were recorded. The patients sedated by midazolam $(0.05$ $\mathrm{mg} \mathrm{kg}^{-1}$ ) 30-45 minutes before surgery.

In the DIl derivation, electrocardiogram (ECG), heart rate $(\mathrm{HR})$, noninvasive systolic arterial blood pressure (SAP), diastolic arterial blood pressure (DAP), mean arterial pressure (MAP), and saturation of peripherical oxygen $\left(\mathrm{SpO}_{2}\right)$ were monitored (Datex-Ohmeda Cardiocap $/ 5^{\circledR}$ ). The first values were recorded as control values and SAP, DAP, MAP, HR and $\mathrm{SpO}_{2}$ values were recorded at 1 st, $3^{\mathrm{rd}}, 5^{\text {th }}, 10^{\text {th }}, 15^{\text {th }}$, $20^{\text {th }}$, 30th $45^{\text {th }}$, 60th, 90th, 120th minutes after the drug application.

Nine percent $\mathrm{NaCl}$ was administered to patients of group S. The patients were laid in the lateral position with the operation side downward. Spinal puncture with midline approach was performed through $\mathrm{L}^{-5}$ or L3 $^{-4}$ intervertebral space to subarachnoid space with a 25 gauge Quincke spinal needle and 1 $\mathrm{mL} 0.5 \%$ levobupivacaine $+1 \mathrm{~mL}$ normal saline (NS) were introduced for 20 seconds. After injection, the patients were laid in lateral decubitus position for 5 minutes.

Sciatic block was applied to the patients in group $B$ with the classic Labat's approach. Lidocaine $2 \%$ was 
used as local anesthetics. Block needles $(150 \mathrm{~mm} ; 1$ Stimuplex D; Braun, Germany) were connected to the nerve stimulator (Stimuplex HNS 12, B. Braun). Aspiration test was performed by stimulation of nerves at a current of $0.5 \mathrm{~mA}$ after obtaining plantar flexion while standing. Of the total $40 \mathrm{~mL}$ local anesthesia (30 $\mathrm{mL} 0.5 \%$ levobupivacaine and $10 \mathrm{~mL} 2 \%$ lidocaine), $15 \mathrm{~mL}$ was injected and then 3in 1 block approach was performed. The patient was immediately turned to supine position, and the femoral nerve block was performed. Stimulation at a current intensity of 1.5-2 $\mathrm{mA}$ was set after skin penetration. A needle $(80 \mathrm{~mm}$, 1 Stimplex D; Braun, Germany) was inserted until observing the contractions of quadriceps femoris muscle and the movements of patella (patellar dance). Then, $25 \mathrm{~mL}$ of $40 \mathrm{~mL}$ local anesthesia was introduced.

The procedure duration was recorded as minute for each procedure. Technical implementation period was defined as the time from the cleaning of the application area by aseptic procedures until the end of the drug injection. Hemodynamic parameters were measured after drug injection. Motor and sensory blocks were evaluated. Following the sensory block development, surgery was started. This duration was recorded as the delivery time for surgery. Anesthetic level as sensory block was evaluated by the pin-prick test. The motor block level was assessed according to the modified Bromage scale. Maximum duration of motor and sensory block was recorded.

When the cases felt any pain (visual analog scale $(0-10 \mathrm{~cm})$ score $>3)$ in any step of the operation, firstly, they were sedated with $2 \mathrm{mg}$ midazolam and if required, with $50 \mu \mathrm{g}$ fentanyl. Quality of anesthesia was evaluated as excellent when no additional drugs was administered, good when benzodiazepine was used, adequatewhenopioid wasused, andinadequate when general anesthesia was needed. The surgery duration was recorded as minute and defined as the time from the beginning of the surgical incision until the last suturation.

Twenty-five percent or a higher decrease in MAP according to basal level was assumed as hypotension and $5 \mathrm{mg}$ ephedrine and $5 \mathrm{~mL} / \mathrm{kg}$ additional IV crystalloid fluid were administered. Bradycardia was defined as a heart rate of $50 / \mathrm{min}$ or lowerand was treated with $0.5 \mathrm{mg}$ atropine. Oxygen $3 \mathrm{~L} / \mathrm{min}$ with mask and $5 \mathrm{~mL} / \mathrm{kg} / \mathrm{h}$ continuous crystalloid fluid were administered to all patients during the surgery. Side effects, such as hypotension, bradycardia, nauseavomiting, and tourniquet pain developed in the intraoperative stage were recorded.

Side effects, such as post-spinal headache, pain in the needle-inserted place, hypoesthesia due to the surgery, paresthesia, temporary neurological symptoms, nausea-vomiting, urinary retention, and hypotension were monitored and evaluated in the postoperative 24 hours. Pethidine was administered IM to patients with postoperative VAS $>3 \mathrm{~cm}$. The first time of analgesic administration, postoperative analgesia duration, and postoperative 24 hours total analgesic consumption were recorded. The time for complete return of motor function and first urine were recorded.

Statistical Analysis

The data was analyzed by SPSS 15 software. The Mann-Whitney $U$ test was used for the comparison of groups in terms of age, height, weight, SAP, DAP, MAP, $\mathrm{HR}, \mathrm{SpO}_{2}$ values, procedure duration, preparation duration for the surgery, surgery duration, motor block duration, time of first urine, time to first analgesic need, and total analgesic consumption. Chisquare test was used for the comparison of groups in terms of gender, ASA score, maximum motor block and sensory block levels, quality of anesthesia, intraoperative and postoperative complications, and the number of patients, who received, additional analgesicafter surgery. The Wilcoxon test was used to analyze the groups with respect to SAP, DAP, MAP, HR, and the change in the $\mathrm{SpO}_{2}$ repetitive measurements. The data was presented as mean \pm standard deviation, patient number, and percentage in tables. A p value of less than 0.05 was considered statistically significant.

\section{Results}

The demographic characteristics of both groups were similar (Table 1). No statistically significant difference was found between the groups in terms of SAP. In group $S$, the increase in the DAP values at baseline, and 20 minute and 60 minute after the blockade and the increase in the MAP at 20th minute were significant. The decrease in the SAP values at $3^{\text {rd }}, 5^{\text {th }}$, and $10^{\text {th }}$ minutes and the decrease in the DAP values at 3 rd minute were significant. Significant decreases in the HR values were observed at 30th, $90^{\text {th }}$ and $120^{\text {th }}$ minutes. In group $B$, no significant difference was found in SAP and DAP values. 
The mean duration of procedure was $3.15 \pm 1.13$ minutes in group $S$ and $12.9 \pm 2.53$ minutes in group $B(p<0.0001)$. Technical implementation period was $8.50 \pm 5.25$ minutes in group $S$ and $7.8 \pm 4.78$ minutes in Group B ( $p=0.781)$.

A statistically significant difference was found between the two groups in baseline Bromage score and maximum sensory level (Table 2, 3).

While no additional sedation or analgesic was administered to the patients in group $S$ in the intraoperative stage, midazolam to 6 subjects, and fentanyl to 1 patient were applied in group B. A significant difference was observed in anesthesia quality between the two groups $(p=0.014)$ (Table 4$)$.

There was no statistically significant difference between the groups in terms of surgery duration. Tourniquet pain and needle pain were observed in 2 patients in Group B during the surgery. Postoperative headache was observed in 1 patient in group $\mathrm{S}$. No significantdifferencewasobservedbetweenthegroups in terms of the postoperative complications, one case in group $S$ having headache while 2 patients each had tourniquet pain and pain in the needle-inserted place.

The motor block duration was $108.05 \pm 66.59$ minutes in group $S$ and $906 \pm 358.89$ minutes in group $B(p<0.001)$. There was no significant difference between the groups in terms of the time of first urine (group S, 282 \pm 116.80 minutes, group B, 277 \pm 129.90 minutes, $p=0.735)$. A statistically significant difference was observed between the groups in terms of the use of additional analgesia after surgery $(p<0.001)$.

Postoperative analgesic was applied to 15 patients in group $S$ and 5 patients in group $B$ and the duration of analgesia was $432 \pm 205.3$ minutes and $837 \pm 374.3$ minutes, respectively ( $p=0.032)$. Postoperative total analgesic consumption was $60 \pm 20.7 \mathrm{mg}$ pethidine in group $S$ and $50 \pm 0 \mathrm{mg}$ pethidine in group $B$. No statistically significant difference was observed.

\section{Discussion}

This study demonstrated that $5 \mathrm{mg}$ of hypobaric levobupivacaine can be used in unilateral surgeries of the lower limbs with a shorter time to perform the anesthesia, smaller number of attempts, shorter duration ofanesthesia, and with thesameeffectiveness as CSFB with $30 \mathrm{~mL} 0.5 \%$ levobupivacaine and $10 \mathrm{~mL}$ $2 \%$ lidocaine. CSFB with the aid of a peripheral nerve stimulator is an easy technique and adverse effects were not observed.

The right choice of local anesthetic for the unilateral anesthesia applications in a day-surgery

Table 1. Baseline characteristics of the both groups

\begin{tabular}{|c|c|c|c|}
\hline & Group $S(n=20)$ & Group B $(n=20)$ & $\mathrm{p}$ \\
\hline Age (years (mean $\pm S D)$ ) & $46.5 \pm 14.8$ & $43.2 \pm 15.4$ & 0.482 \\
\hline Sex (Female/Male) & $8 / 12$ & 9/11 & 1.000 \\
\hline Weight (kg (mean \pm SD)) & $78.6 \pm 10.7$ & $76.9 \pm 10.07$ & 0.694 \\
\hline Height (cm (mean \pm SD)) & $168.7 \pm 9.6$ & $168.2 \pm 10.1$ & 0.892 \\
\hline ASA status (I/II) & $15 / 5$ & $15 / 5$ & 1.000 \\
\hline
\end{tabular}

\begin{tabular}{|c|c|c|c|c|c|c|c|c|}
\hline \multirow[b]{3}{*}{ Score } & \multicolumn{4}{|c|}{ Operated side } & \multicolumn{4}{|c|}{ Non operated side } \\
\hline & \multicolumn{2}{|c|}{ Group S $(n=20)$} & \multicolumn{2}{|c|}{ Group B $(n=20)$} & \multicolumn{2}{|c|}{ Group S $(n=20)$} & \multicolumn{2}{|c|}{ Group B $(n=20)$} \\
\hline & $\mathrm{n}$ & $\%$ & $n$ & $\%$ & $\mathrm{n}$ & $\%$ & $\mathrm{n}$ & $\%$ \\
\hline 0 & 5 & 25 & 0 & 0 & 15 & 75 & 20 & 100 \\
\hline 1 & 6 & 30 & 15 & 75 & 4 & 20 & 0 & 0 \\
\hline 2 & 6 & 30 & 5 & 25 & 1 & 5 & 0 & 0 \\
\hline 3 & 3 & 15 & 0 & 0 & 0 & 0 & 0 & 0 \\
\hline \multirow[t]{2}{*}{ Total } & 20 & 100 & 20 & 100 & 20 & 100 & 20 & 100 \\
\hline & \multicolumn{3}{|c|}{$p=0.008$} & & \multicolumn{4}{|c|}{$p=0.022$} \\
\hline
\end{tabular}


setting is the subject of debate. In the present study, $1 \mathrm{~mL} 5.0 \mathrm{mg}$ 0.5\% levobupivacaine and 1 $\mathrm{mL}$ NS were used to provide spinal anesthesia for outpatient arthroscopic knee surgery. The aim was to stabilize the hemodynamic parameters and establish postoperative early mobilization, besides, to provide anesthesia with the possible lowest dose anesthetic for this short operation. According to the literature, $5.0 \mathrm{mg}$ levobupivacaine is adequate for arthroscopic knee surgery $(9,10)$. Therefore, this dose was used in the present study. In the literature, there is no study in which lower doses were used for unilateral spinal anesthesia. When the related studies were considered, $30 \mathrm{~mL} 0.5 \%$ levobupivacaine $+10 \mathrm{~mL}$ $2 \%$ lidocaine were used for CSFB (11-14). Because levobupivacaine does not act immediately, it was combined with a local anesthetic, lidocaine that acts, more speedily.

In the present study, the duration of lying in lateral position was determined as 5 minutes and the intrathecal injection was applied for 20 seconds. In studies using hyperbaric bupivacaine, to position the patient in lateral position for 10-20 minutes was suggested for intensifying block for unilateral spinal anesthesia (15). In our preliminary studies, it was determined that 5 minutes lying in lateral position was sufficient. Limited motor block at contralateral side is a desired condition in one-sided block. In addition, the duration of preparation for the surgery includes the duration of lateral lying which is a waiting period for the effect of the unilateral spinal anesthesia. Even though the lateral waiting duration was 5 minutes in this study, motor blockage at contralateral side was developed in only 5 cases. The maximum Bromage score was 1 in 4 of them, while it increased to 2 in one subject.

In a study on outpatient arthroscopic knee surgery conducted by Breebaart et al., the maximum sensory level was determined to be T8 for the unilateral spinal anesthesia with $10 \mathrm{mg}$ levobupivacaine

\begin{tabular}{|c|c|c|c|c|c|c|c|c|}
\hline \multirow{3}{*}{ Maximum sensorial block level } & \multicolumn{4}{|c|}{ Operated side } & \multicolumn{4}{|c|}{ Non operated side } \\
\hline & \multicolumn{2}{|c|}{ Group S $(n=20)$} & \multicolumn{2}{|c|}{ Group B $(n=20)$} & \multicolumn{2}{|c|}{ Group S $(n=20)$} & \multicolumn{2}{|c|}{ Group B $(n=20)$} \\
\hline & $\mathrm{n}$ & $\%$ & $\mathrm{n}$ & $\%$ & $\mathrm{n}$ & $\%$ & $\mathrm{n}$ & $\%$ \\
\hline No sensorial block & 0 & 0 & 0 & 0 & 8 & 40 & 0 & 0 \\
\hline L1-2 & 0 & 0 & 20 & 100 & 6 & 30 & 0 & 100 \\
\hline $\mathrm{T} 12$ & 6 & 30 & 0 & 0 & 6 & 30 & 0 & 0 \\
\hline T11 & 1 & 5 & 0 & 0 & 0 & 0 & 0 & 0 \\
\hline T10 & 7 & 35 & 0 & 0 & 0 & 0 & 0 & 0 \\
\hline T9 & 0 & 0 & 0 & 0 & 0 & 0 & 0 & 0 \\
\hline T8 & 6 & 30 & 0 & 0 & 0 & 0 & 0 & 0 \\
\hline \multirow[t]{2}{*}{ Total } & 20 & 100 & 20 & 100 & 20 & 100 & 20 & 100 \\
\hline & & \multicolumn{2}{|c|}{$\mathrm{p}<0.001$} & & \multicolumn{4}{|c|}{$p<0.001$} \\
\hline
\end{tabular}

Table 4. Quality of anesthesia assessed by anaesthetist in both groups

\begin{tabular}{|c|c|c|c|c|c|}
\hline & Gro & $S(n=20)$ & Gro & $B(n=20)$ & Total \\
\hline & $\mathrm{n}$ & $\%$ & $n$ & $\%$ & \\
\hline Inadequate & 0 & 0 & 0 & 0 & 0 \\
\hline Adequate & 0 & 0 & 1 & 5 & 1 \\
\hline Good & 0 & 0 & 6 & 30 & 6 \\
\hline Excellent & 20 & 100 & 13 & 65 & 33 \\
\hline
\end{tabular}


(16). Casati et al. (18) have also reported that the maximum sensory block level was $\mathrm{T} 8$ in inguinal hernia operation performed by using $8 \mathrm{mg} 0.5 \%$ hyperbaric levobupivacaine (17). Cappelleri et al. (1) have demonstrated that while the median maximum sensory block level was $T^{8}\left(T^{7}-T^{9}\right)$ in unilateral spinal anesthesia with 7.5 hyperbaric levobupivacaine for arthroscopic knee surgery, it was T10 (T7-T10) with 5 mg levobupivacaine. Lateral waiting duration was 15 minutes in all above mentioned three studies. In the present study, the maximum sensory block level was lower, $\mathrm{T}^{10}$ (T8-T12), however, sufficient anesthesia for the operation could be provided. In this study, while statistically significant decreases in the SAP, DAP, $\mathrm{HR}$ and $\mathrm{SpO}_{2}$ levels were observed in group $\mathrm{S}$, no difference was found in hemodynamic parameters in group B.

Although the time of administration of CSFB was longer than the time of administration of spinal anesthesia (12.9 \pm 2.53 minute - $3.15 \pm 1.13$ minute, respectively), the duration of preparation for surgery was similar in both procedures $(7.8 \pm 4.78$ minute - $8.50 \pm 5.25$ minute, respectively). The duration of administration of CSFB was longer because more than one blockage was applied to achieve success $(18,19)$. In group $B$, the long time needed to introduce the anesthesia procedure could be explained by the repositioning of the patient from lateral position to supine position in peripheral nerve block. This difference in the duration can be decreased by using a blocking room rather than an operation room $(20,21)$.

Sufficient pain management is essential for early and easy rehabilitation after knee arthroscopy. There arefewstudiesinvestigatingtheeffectofpostoperative analgesics. In a study conducted by Montes et al. (20), analgesia following CSFB in the postoperative 6 hours has been reported to be better than spinal anesthesia and it has been correlated with the significantly low pain score (20). In another study conducted with 40 $\mathrm{mL} 1 \%$ mepivacaine, CSFB and spinal anesthesia with $7 \mathrm{mg}$ hyperbaric bupivacaine were compared. It has been reported that medical treatment was needed after 230 minute in spinal anesthesia group and after 310 min in sciatic and femoral block group, for one patient in each group at postoperative period (8). In a study investigating the sciatic and femoral block and spinal anesthesia conducted by Casati et al., (22) it has been reported that postoperative analgesia was provided for all groups. While any patient has received any analgesics in the sciatic and femoral group, tramadol on analgesia purpose was administered to 4 (16\%) patients in spinal group along the postoperative 24 hours. In the present study, similar with the mentioned study, a significant difference was observed between the groups in terms of postoperative analgesia need.

In a study by Montes el al. (20), adequate anesthesia could not be provided by femoral sciatic block in one of 25 patients, however, in another study by Fanelli et al. (23), this rate has been reported as $4 \%$ (21). The failure rate of spinal anesthesia with lowdose bupivacaine ranges between $3 \%$ and $6 \%$ (24). These findings have suggested that both methods have similar anesthetic efficacy in outpatient knee surgery and there is no difference in terms of success rate in practical terms. In the present study, sufficient anesthesia was provided by both procedures. In addition, the difference between the groups in terms of anesthesia quality was found to be statistically significant $(p=0.014)$.

Anesthesia can be insufficient in femoral 3-in-1 block due to the low distribution of local anesthetic agent to the obturator and lateral femoral cutaneous nerves and swollen tourniquet can cause serious pains in patients with insufficient anesthesia (25). In the present study, the need for additional sedative and analgesic drugs was considered to be due to this, as well.

Since the side effects and complications related with the anesthesia method affect the hospitalization duration of patients, anesthesia methods and anesthetic agents are very important. The important factors affecting this duration are the retardation of the time for complete return of motor and bladder functions after spinal anesthesia (26). In the present study, the resolution of nerve block was faster in group $S$ and the duration of first urine was longer ( $282 \pm 116.8$ minutes $-277 \pm 129.9$ minutes), however, there was no significant difference that would affect the hospitalization duration. In the present study, urine retention was not observed in any patients.

Same side extremity motor block duration is the main factor affecting the hospitalization duration. In the present study, the total duration of the motor blockage was statistically significant $(p<0.001)$. In group S, motor block duration was $108.05 \pm 66.59$ 
minutes, while it was $906 \pm 358.89$ minutes in group $B$. Our results were similar with the studies conducted with levobupivacaine $(11,13)$.

This study has certain limitations. Firstly, to use the ultrasound can be suggested for CSFB. This would shorten procedureduration ofCSFB. EventhoughCSFB wasadministered by mixing with levobupivacaine that has a short efficacy, it had relatively long preoperative duration. Inaddition, themean motorblockduration of 15 hours was the factor that extended hospitalization. To use only short acting local anesthetic or lower doses of levobupivacaine can be suggested for outpatient arthroscopic surgery. This would shorten motor block duration and decrease the hospitalization duration. Even short acting local anesthetic shortens the postoperative analgesic duration, it has higher analgesia duration than spinal anesthesia. Although thenumberofparticipantsinthisstudywasnotenough for the observation of some other complications, such as cardiovascular and neurological complications or post-dural puncture headache and urinary retention, no significant complication was observed in unilateral anesthesia with a very low levobupivacaine dose. In this study, the effect of peripheral nerve blockage on hemodynamic parameters was found to be lower than the spinal anesthesia. In conclusion, it was considered that the CSFB could be a good alternative to other anesthesia proceduresforhigh-riskpatients, especially cardiac patients. The most suitable anesthetic method for outpatients should be evaluated by specialists considering these results.

In conclusion, both unilateral spinal anesthesia with low doses of levobupivacaine and combined sciatic and femoral block procedures provided sufficient anesthesia for outpatients who were planned to undergo elective knee arthroscopy.

Ethics Committee Approval: The study were approved by the Süleyman Demirel University of Local Ethics Committee, Informed Consent: Consent form was filled out by all participants, Concept: Sinem Sarı, Füsun Eroğlu, Design: Sinem Sarı, Füsun Eroğlu, Francesco Fusco, Data Collection or Processing: Sinem Sarı, Füsun Eroğlu, Tolga Atay, Analysis or Interpretation: Sinem Sarı, Füsun Eroglu, Berit Ceylan, Literature Search: Sinem Sarı, Writing: Sinem Sarı, Füsun Eroğlu, Berit Ceylan, Peer-review: Externally peer-reviewed, Conflict of Interest: No conflict of interest was declared by the authors, Financial Disclosure: The authors declared that this study has received no financial support.

\section{References}

1. Cappelleri G, Aldegheri G, Danelli G, Marchetti C, Nuzzi $M$, lannandrea $G$, et al. Spinal anesthesia with hyperbaric levobupivacaine and ropivacaine for outpatient knee arthroscopy: a prospective, randomized, double-blind study. Anesth Analg 2005; 101: 77-82.

2. Swiniarski D, Fabi J, Kubiak G. Comparison of cost-effectiveness in knee arthroscopy performed under local, general intravenous and spinal anesthesia. Chir Narzadow Ruchu Ortop Pol 2005; 70:211-5.

3. Korhonen AM, Valanne JV, Jokela RM, Ravaska P, Korttila KT. A comparison of selective spinal anesthesia with hyperbaric bupivacaine and general anesthesia with desflurane for outpatient knee arthroscopy. Anesth Analg 2004; 99: 1668-73.

4. Meyhoff CS, Haarmark C, Kanters JK, Rasmussen LS. Is it possible to predict hypotension during onset of spinal anesthesia in elderly patients? J Clin Anesth 2009; 21: 23-9.

5. Salinas FV, Joseph RS. Peripheral nerve blocks for ambulatory surgery. Anesthesiol Clin 2014; 32: 341-55.

6. Esmaoglu A, Karaoglu S, Mızrak A, Boyaci A. Bilateral vs. unilateral spinal anesthesia for outpatient knee artroscopies. Knee Surg Sports Traumatol Artrosc 2004; 12: 155-8.

7. Fanelli G, Casati A, Aldegheri G, Beccaria P, Berti M, Leoni A, et al. Cardiovascular effects of two different regional anaesthetic techniques for unilateral leg surgery. Acta Anaesthesiol Scand. 1998; 42: 80-4.

8. Moosavi Tekye SM, Alipour M. Comparison of the effects and complications of unilateral spinal anesthesia versus standard spinal anesthesia in lower-limb orthopedic surgery. Braz J Anesthesiol 2014; 64: 173-6.

9. Spasiano A, Flore I, Pesamosca A, Della Rocca G. Comparison between spinal anaesthesia and sciatic-femoral block for arthroscopic knee surgery. Minerva Anestesiol 2007; 73: 13-21.

10. Sell A, Olkkola KT, Jalonen J, Aantaa R. Minumum effective local anaesthetic dose of isobaric levobupivacaine and ropivacaine administered via a spinal catheter for hip replacement surgery. Br J Anaesth 2005; 94: 239-42.

11. Parpaglioni $R$, Frigo MG, Lemma $A$, Sebastiani $M$, Barbati $G$, Celleno D. Minimum local anaesthetic dose (MLAD) of intrathecal levobupivacaine and ropivacaine for Caesarean section. Anaesthesia 2006; 61: 110-5.

12. Urbanek B, Duma A, Kimberger O, Huber G, Marhofer P, Zimpfer $M$, et al. Onset time, quality of blocade and duration of three-inone blocks with levobupivacaineand bupivacaine. Anesth Analg 2003; 97: 888-92.

13. Casati A, Chelly JE, Cerchierini E, Santorsola R, Nobili F, Grispigni C, etal.Clinical properties oflevobupivacaineorracemicbupivacaine for sciatic nerve block. J Clin Anesth 2002; 14: 111-4.

14. Casati A, Borghi B, Fanelli G, Cerchierini E, Santorsola R, Sassoli V, et al. A double-blinded, randomized comparison of either $0.5 \%$ levobupivacaine or $0.5 \%$ ropivacaine for sciatic nerve block. Anesth Analg 2002; 94: 987-90.

15. Casati A, Vinciguerra F, Santorsola R, Aldegheri G, Putzu M, Fanelli G. Sciatic nerve block with $0.5 \%$ levobupivacaine, 
$0.75 \%$ levobupivacaine or $0.75 \%$ ropivacaine: a double-blind, randomized comparison. Eur J Anaesthesiol 2005; 22: 452-6.

16. Kuusniemi KS, Pihlajamaki KK, Pitkanen MT. A low dose of plain or hyperbaric bupivacaine for unilateral spinal anesthesia. Reg Anesth Pain Med 2000; 25: 605-10.

17. Breebaart MB, Vercauteren MP, Hoffmann VL, Adriaensen HA. Urinary bladder scanning after day-case arthroscopy under spinal anaesthesia:comparison between lidocaine, ropivacaine, and levobupivacaine. Br J Anaesth 2003; 90: 309-13.

18. Casati A,PutzuM.Bupivacaine, levobupivacaineandropivacaine: are they clinically different? Best Pract Res Clin Anaesthesiol 2005; 19: 247-68.

19. Casati A, Cappelleri G, Berti M, Fanelli G, Di Benedetto P, Torri G. Randomized comparison of remifentanil-propofol with a sciatic-femoral nerve block for out-patient knee arthroscopy. Eur J Anaesthesiol 2002; 19: 109-14.

20. Montes F, Zarate E, Grueso R, Giraldo JC, Venegas MP, Gomez $A$, et al. Comparison of spinal anesthesia with combined sciaticfemoral nerve block for outpatient knee arthroscopy. J of Clin Anesth 2008; 20: 415-20.
21. Kiran S, Upma B. Use of small-dose bupivacaine (3 mg vs $4 \mathrm{mg}$ ) for unilateral spinal anesthesia in the outpatient setting. Anesth Analg 2004; 99: 302-3.

22. Casati A, Cappelleri G, Fanelli G, Borghi B, Anelati D, Berti M, et al. Regional anaesthesia for outpatient knee arthroscopy: a randomized clinical comparison of two different anaesthetic techniques. Acta Anaesthesiol Scand 2000; 44: 543-7.

23. FanelliG, Casati A, GaranciniP,TorriG. Nerve stimulator and multiple injection technique for upper and lower limb blockade: failure rate, patient acceptance, and neurologic complications. Study Group on Regional Anesthesia. Anesth Analg 1999; 88: 847-52.

24. JankowskiCJ,HeblJR,StuartMJ,RockMG,PagnanoMW, Beighley $\mathrm{CM}$, et al. A comparison of psoas compartment block and spinal and general anesthesia for outpatient knee arthroscopy. Anesth Analg 2003; 97: 1003-9.

25. Korhonen AM, Valanne JV, Jokela RM, Ravaska P, Korttila KT. A comparison of selective spinal anesthesia with hyperbaric bupivacaine and general anesthesia with desflurane for outpatient knee arthroscopy. Anesth Analg 2004; 99: 1668-73.

26. Enneking FK, Chan V, Greger J, Hadzic A, Lang Scott A, Horlocker TT. Lower extremity peripheral nerve blockade: essentials of our current understanding. Reg Anesth Pain Med 2005; 30: 4-35. 